\title{
THE USE OF FIVES STRATEGY TO TEACH READING COMPREHENSION FOR ELEVENTH GRADERS
}

\author{
${ }^{1}$ Septika Sari*, ${ }^{1}$ Ayu Oktaviani, \& ${ }^{1}$ Yulfi \\ ${ }^{1}$ STKIP-PGRI Lubuklinggau, Indonesia \\ *Corresponding Author: septikanewid999@gmail.com
}

\begin{abstract}
One of the objectives that should be developed in teaching is reading comprehension skills. In fact, many students still have a lot of problems with reading. Therefore, teachers should use specific strategies in teaching reading comprehension to resolve students' difficulties. The purpose of the research was to find out whether or not it is significantly effective to teach reading comprehension by using the FIVES strategy for eleventh-grade students of SMA Negeri 2 Lubuklinggau. This research applied the pre-experimental method with one group pre- and post-test only. The population of the study was all of the eleventh-grade students of SMA Negeri 2 Lubuklinggau. Cluster random sampling was taken to take the sample class. Class XI MIA 4 was chosen as the sample class. The data was collected through a reading test consisted of 20 items of multiple-choice form. The results of this research were: 1) the average score in the pre-test was 61.81 , and the post-test was $78.06,2)$ the result of the Paired t-test was 10.167, which higher than t-table (1.689) at the significant level of $5 \%$ with df 35 . Therefore, the alternative hypotheses ( $\mathrm{Ha}$ ) was accepted. It means that it was significantly effective to teach reading comprehension by using the FIVES strategy for eleventh-grade students of SMA Negeri 2 Lubuklinggau.
\end{abstract}

Keywords: FIVES Strategy; Reading Comprehension; Teaching

\begin{abstract}
ABSTRAK
Salah satu tujuan yang harus ditingkatkan dalam mengajar adalah pemahaman membaca. Faktanya, banyak siswa masih mempunyai kesulitan dalam membaca. Oleh karena itu, guru sebaiknya menggunakan strategi khusus dalam mengajar bahasa Inggris demi meningkatkan pemahaman membaca untuk mengatasi kesulitan siswa. Tujuan dari penelitian ini adalah untuk mengetahui apakah efektif atau tidak untuk mengajar pemahan membaca menggunakan FIVES strategi kepada siswa kelas sebelas di SMA Negeri 2 Lubuklinggau. Penelitian ini menggunakan metode pre-experimental dengan menggunakan satu grup dengan tes sebelum dan sesudah perlakuan. Populasi dari penelitian ini adalah seluruh siswa kelas sebelas di SMA Negeri 2 Lubuklinggau. Sampel Kelompok Acak digunakan dalam mengambil kelas sampel pada penelitian ini. Kelas XII MIA 4 dipilih sebagai kelas sampel. Data diambil melalui tes membaca berisikan 20 item soal dalam bentuk pilihan ganda. Hasil dari penelitian ini, antara lain: 1) Ratarata skor sebelum diberikan perlakuan adalah 61.81 dan setelah diberikan perlakuan adalah 78.06. 2) Hasil dari tes-t berpasangan adalah 10.167, lebih besar dari tabel-t (1.689) pada tingkat signifikansi 5\% dengan derajat kebebasan 35. Oleh karena itu, Hipotesis kerja (Ha) diterima. Dengan kata lain, strategi FIVES efektif untuk mengajar pemahaman membaca pada siswa kelas sebelas di SMA Negeri 2 Lubuklinggau.
\end{abstract}

Kata Kunci: Strategi FIVES; Mengajar; Pemahaman Membaca 
Celtic: A Journal of Culture, English Language Teaching, Literature and Linguistics

Vol. 7, No. 1, June 2020.

E-ISSN: 2621-9158 P-ISSN:2356-0401

http://ejournal.umm.ac.id/index.php/celtic/index

\section{INTRODUCTION}

Teaching English includes four skills; they are listening, writing, speaking, and reading. One of the skills that should be studied by students is reading. As one of the four skills in English, reading is an extremely complex and multifaceted process, and assessing this process is also complex and multifaceted (Caldwell, 2008:2). Reading is one of the critical skills in English, and it is also a common way to get information. Reading is an important activity for students in getting a lot of information in the text content that the writer has delivered (Syaprizal, 2016:26). On the other hand, Tankersley (2003:92) stated that readers must understand that reading is an interactive process that involves both decoding words and deriving meaning from the words. By reading, people can get a lot of information from the book, magazine, newspaper, and internet also. Especially for students, reading activity plays a vital role in developing students' abilities in English. Through reading, they can know about the meaning and also what the text is about. In other words, reading can increase their knowledge by getting information.

According to Rukmayadi in Hadyan (2013:58), one of the objectives that should be developed in teaching is reading comprehension skills. It is suitable for students to train themselves to read well and have a good skill in comprehending the text, and they can get more information and understand the text easily. According to Teale \& Yokota in Westwood (2001:9), comprehension must be the central focus of teaching children to read and not something to be emphasized only after children have learned how to decode and identify words. Besides that, they also have other purposes, such as understanding the meaning feeling that the writer tries to convey in the text in learning reading, especially reading comprehension. In fact, many students face some difficulties in comprehending the text well. It means that they still have low reading comprehension skills, although reading comprehension has been learned by them since they were at Junior High School.

While the circumstance which was found in the SMA Negeri 2 Lubuklinggau showed that students have difficulties in learning English, especially in reading, from interviews with the English teacher, the researcher found that the students had some difficulties related to their reading comprehension. It is because of some reasons. First, students were lack of vocabulary. They faced difficulty in guessing the meaning of unknown words. Second, they were not interested in learning English, especially reading comprehension. Basically, a successful reading comprehension process also depends on students' interest in reading (Antoni, 2017:74).

It showed that in SMA Negeri 2 Lubuklinggau, the students still have a lot of problems in reading, and the researcher realizes that the teacher should use a certain strategy in teaching English especially reading comprehension to resolve the students' difficulties. The teacher needs to prepare a certain technique, especially in teaching reading (Nuriati, Ohoiwutun \& Mashuri, 2015). There are many techniques that teachers can apply to teach reading, one of them is the FIVES strategy by Shea and Roberts (2016).

According to Shea and Roberts (2016:97), the letters in FIVES refer to Facts, Inferences, Vocabulary, Experiences, and Summary. This strategy introduced by Mary Shea and Nancy Roberts in 2016. This strategy emphasizes all English skills for learning (integrated strategy). FIVES require the students for success in the micro and 
Sari, S., Oktaviani, A. \& Yulfi. (2020). The use of fives strategy to teach reading comprehension for eleventh graders. Celtic: A Journal of Culture, English Language Teaching, Literature, \& Linguistics, 7(1), 74-82.

macro aspect of reading comprehension. As Shea and Roberts (2016:97) state that FIVES strategy supports the student to understand the micro and macro elements of reading comprehension and writing to learn by through the integration skills used to complete the FIVES components. Based on the reasons above, the researcher is interested in conducting the research entitled: The Use of Fives Strategy to Teach Reading Comprehension for The Eleventh Grade Students. The purpose of the study was to find out whether or not it is significantly effective teaching reading comprehension by using the FIVES strategy for eleventh-grade students of SMA Negeri 2 Lubuklinggau.

\section{METHOD}

In the research, the researcher applied the pre-experimental method. According to Walliman (2011:106), the pre-experimental method does not have control class to compare with the experiment group which will be given a test before and also after the treatment. The kind of pre-experimental method of the research was one group, pre and post-test only. One class was taken as a sample, and it was called the experimental group. The experimental class was taught by using the FIVES strategy to increase the students' reading comprehension.

The population of the research was all eleventh-grade students at SMA Negeri 2 Lubuklinggau. There are ten classes that consist of 5 social classes and 5 science classes. On average, all comprised of 36 students. The total number of eleventh class at SMA Negeri 2 Lubuklinggau are 354 students. The researcher used the cluster random technique in taking the sample class. According to Fraenkell \& Wallen (2009:95) defined that cluster random sampling is selecting groups, or clusters, of subjects that already exist rather than individuals. In this research, class XI MIA 4 was chosen as the sample which consists of 36 students.

In this study, the researcher applied reading tests for collecting the data. According to Brown (2004:3), a test is a way or a procedure of measuring an individual's ability or performance in a given domain. The test was a multiple-choice form. Before delivering the test to the sample students, the test was tried out to find out the validity and reliability of the test. According to Gay, Mills \& Airasian (2012:160), reliability is the degree to which a test consistently measures its purpose.

Based on the result of try out, the researcher gave the test to the students consist of 20 items for 40 minutes to finish the test in pre-test and post-test. The student gave the test twice by the researcher, the first test was given before the students received the treatment (pre-test), and the second test was given after the students received the treatment (post-test). The test was the same in the pre-test and post-test.

Then, in analyzing the data, the researcher used four techniques, they were: 1) Individual Score; the technique applied to find out the students' scores. 2) Minimum Mastery Criteria (MMC). The students are categorized as passed if the score equals or higher than MMC. 3) The normality test is analyzed by using Pearson Product Moment (SPSS statistics 23). A normality test was done to find out whether the subject is normally distributed or not (Rustam, 2016:57). 4) Paired t-test. The data analyzed through Person Product Moment (SPSS version 23). 
Celtic: A Journal of Culture, English Language Teaching, Literature and Linguistics

Vol. 7, No. 1, June 2020.

E-ISSN: 2621-9158 P-ISSN:2356-0401

http://ejournal.umm.ac.id/index.php/celtic/index

\section{FINDINGS}

The result of this research is explained below:

\section{The Result of the Pre-test}

In this research, a pre-test was applied in order to recognize students' ability in reading before applying the treatment. The researcher gave a pre-test to obtain the score. After the score of the pre-test was calculated, the researcher found that most of the students were not able to answer the test. It can observe from the score in the pre-test. The result of pre-test can be presented as follows:

Table 1. The Result of Pre-test

\begin{tabular}{ll}
\hline Component & Pre-test Score \\
\hline Total of students & 36 \\
Average & 61.81 \\
Highest score & 90 \\
Lowest score & 45 \\
Total of students who failed & 29 \\
Total of students who passed & 7 \\
\hline
\end{tabular}

Based on the table, it can be seen that the average score of the pre-test was 61.81. For the Minimum Mastery Criteria of SMA Negeri 2 Lubuklinggau was 71. So, the students failed in the pre-test. The total students who passed in the pre-test were 7 students or $19.4 \%$, and students who failed in the pre-test were 29 students or $80.6 \%$. Based on the data above, the researcher assumed that students still have difficulties in reading comprehension.

\section{The Students' Score in Post-test}

The post-test was given to observe the improvement of students' scores in reading comprehension after giving treatments. Before giving a post-test, the students were taught by using FIVES Strategy. The test given to the students in the pre and posttest was the same. The result of the students' score in post-test is presented as follows:

Table 2. The Result of Students' Score in post-test

\begin{tabular}{lll}
\hline \multicolumn{1}{c}{ Component } & Post-test Score \\
\hline Total of Students & 36 & \\
Average & 78.06 & \\
Highest Score & 90 & \\
Lowest Score & 60 & \\
Total of students who failed & 6 & \\
Total of Students Who Passed & 30 & \\
\hline
\end{tabular}

Based on the result of the post-test score, the average was 78.06. So, most students passed in the post-test. Based on the Minimum Mastery Criteria (MMC), the researcher found that the total students who passed were 30 students or $83.3 \%$, and students who failed were 6 students or $16.7 \%$. Based on the result, the researcher assumed that the students mastered the material well, and teaching reading comprehension by using the FIVES strategy was significantly effective. It can observe from the improvement of students' scores in the post-test. 
Sari, S., Oktaviani, A. \& Yulfi. (2020). The use of fives strategy to teach reading comprehension for eleventh graders. Celtic: A Journal of Culture, English Language Teaching, Literature, \& Linguistics, 7(1), 74-82.

\section{The Result of Pre-test and Post-test}

Based on the finding of this research, the researcher found that after the students were taught by using FIVES Strategy, the students' scores in the pre-test and post-test were improved. The students' scores in the post-test were higher than in the pre-test. The comparison between students' score in pre-test and post-test was shown in this following chart:

Figure 3. The Comparison of the Average Score in Pre-Test and Post-Test

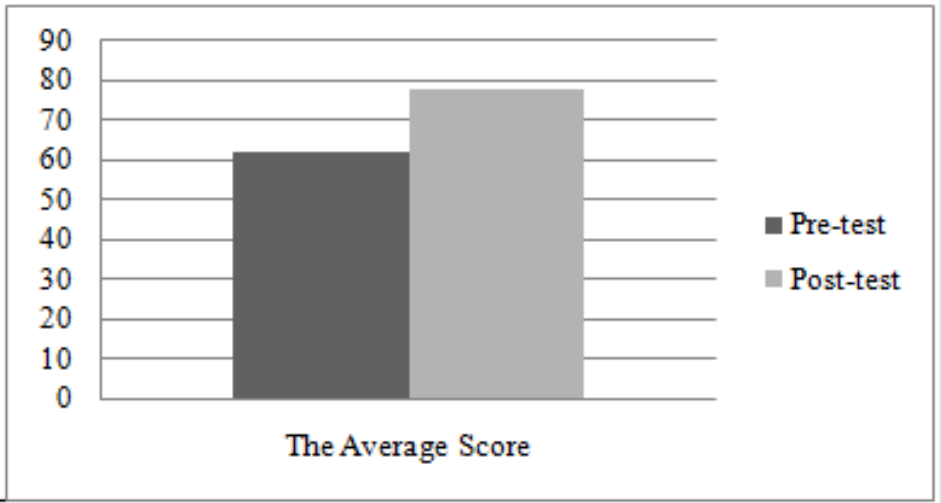

\section{Test of Normality}

The result of normality testing presented in the table:

Table 4. Test of Normality

\begin{tabular}{|ll|r|r|r|r|r|r|}
\hline & \multicolumn{3}{|c|}{ Kolmogorov-Smirnov a } & \multicolumn{3}{|c|}{ Shapiro-Wilk } \\
\cline { 2 - 8 } & Pre-test & Statistic & $\mathrm{df}$ & \multicolumn{1}{c|}{ Sig. } & Statistic & \multicolumn{1}{c|}{ df } & \multicolumn{1}{c|}{ Sig. } \\
\hline Post-test & 45 &, 231 & 5 &, $200^{*}$ &, 881 & 5 &, 314 \\
& 50 &, 360 & 5 &, 033 &, 767 & 5 &, 042 \\
& 55 &, 231 & 5 &, $200^{*}$ &, 881 & 5 &, 314 \\
60 &, 231 & 5 &, $200^{*}$ &, 881 & 5 &, 314 \\
70 &, 302 & 6 &, 094 &, 775 & 6 &, 035 \\
&, 385 & 3 & &, 750 & 3 &, 000 \\
&, 260 & 2 & & & & \\
\hline
\end{tabular}

Based on the table of normality testing above, the researcher found that the Shapiro-Wilk test results were as follows: a) Statistic normality of 45 was 0.881 with the degree of freedom (df) was 5, and the Significance of normality of 45 was 0.314 . b) Statistic normality of 50 was 0.767 , with the degree of freedom (df) was 5 , and the Significance of normality of 50 was 0.042 . c) Statistic normality of 55 was 0.881 , with the degree of freedom (df) was 5, and the Significance of normality of 55 was 0.314 . d) Statistic normality of 60 was 0.881 , with the degree of freedom (df) was 5, and the Significance of normality of 60 was 0.314 . e) Statistic normality of 70 was 0.775 , with the degree of freedom (df) was 6, and the Significance of normality of 70 was 0.035 . f) Statistic normality of 75 was 0.750 , with the degree of freedom (df) was 3 , and the Significance of normality of 75 was 0.000 . Based on the normality testing, it is showed that the pre and post-test were distributed normally. 
Celtic: A Journal of Culture, English Language Teaching, Literature and Linguistics

Vol. 7, No. 1, June 2020.

E-ISSN: 2621-9158 P-ISSN:2356-0401

http://ejournal.umm.ac.id/index.php/celtic/index

\section{The Result of Paired Sample T-test}

After the researcher obtained the students' scores in pre-test and post-test, and the test of normality was analyzed. Then, the researcher calculated the paired sample ttest to find out whether or not it was significantly effective to teach reading comprehension by using the FIVES strategy to the eleventh-grade students of SMA Negeri 2 Lubuklinggau. The result of the paired sample t-test calculation can be seen in the following table:

Table 5. Paired Sample Statistics

\begin{tabular}{ll|l|l|l|l}
\hline & \multicolumn{1}{|c|}{ Mean } & \multicolumn{1}{|c|}{$\mathrm{N}$} & \multicolumn{1}{|c}{ SD } & $\begin{array}{c}\text { Standard } \\
\text { Error Mean }\end{array}$ \\
\hline Pair & Post-test & 78.06 & 36 & 8.04 & 1.34 \\
1 & Pre-test & 61.81 & 36 & 12.31 & 2.05 \\
\hline
\end{tabular}

As mentioned in the table, the researcher found that before giving the treatment, the number of students was 36 with the mean of 61.81, the standard deviation was 12.31, and the standard error mean was 2.05. While after the students were given the treatment, the number of students was 36 with a mean of 78.06, the standard deviation was 8.04, and the standard error mean was 1.34 , which means that mean of students' scores improved from 61.81 to 78.06 . The improvement of students' scores in pre and post-test showed that students' reading comprehension had improved.

Table 6. Paired Sample Correlation

\begin{tabular}{|ll|r|r|c|}
\hline & & N & Correlation & Sig. \\
\hline Pair 1 & Post-test \& Pre-test & 36 &, 628 &, 000 \\
\hline
\end{tabular}

As mentioned on the table of paired sample correlation above, the result of the correlation was 0.628 , with a significance of 0.000 . It means that there was a correlation between students' scores in pre-test and post-test.

Table 7. Paired Sample T-test

\begin{tabular}{|c|c|c|c|c|c|c|c|c|c|}
\hline & & \multicolumn{5}{|c|}{ Paired Differences } & \multirow{3}{*}{$\mathrm{t}$} & \multirow{3}{*}{ df } & \multirow{3}{*}{$\begin{array}{c}\text { Sig. } \\
(2- \\
\text { tailed) }\end{array}$} \\
\hline & & \multirow[t]{2}{*}{ Mean } & \multirow[t]{2}{*}{$\begin{array}{c}\text { Std. } \\
\text { Deviation }\end{array}$} & \multirow[t]{2}{*}{$\begin{array}{c}\text { Std. Error } \\
\text { Mean }\end{array}$} & \multicolumn{2}{|c|}{$\begin{array}{c}95 \% \\
\text { Confidence } \\
\text { Interval of the } \\
\text { Difference }\end{array}$} & & & \\
\hline & & & & & Lower & Upper & & & \\
\hline $\begin{array}{c}\text { Pair } \\
1\end{array}$ & $\begin{array}{l}\text { Post-test - } \\
\text { Pre-test }\end{array}$ & 16,250 & 9,590 & 1,598 & 13,005 & 19,495 & 10,167 & 35 &, 000 \\
\hline
\end{tabular}

Based on the table of paired sample t-test above, it was shown that the result of the paired sample t-test both pre-test and post-test was 10.167. Meanwhile, the critical value of $95 \%$ with the degree of freedom (df) was 35, the significance level was 0.05 , and the result of the t-table was 1.689. Whereas the result of the mean was 16.250, the standard deviation was 9.590, the standard error mean was 1.598, and the significance was 0.000 . It can be concluded that the result of t-test $=10.167>\mathrm{t}$-table $=1.689$. It means that the null hypothesis was rejected. So, the alternative hypothesis was accepted, 
Sari, S., Oktaviani, A. \& Yulfi. (2020). The use of fives strategy to teach reading comprehension for eleventh graders. Celtic: A Journal of Culture, English Language Teaching, Literature, \& Linguistics, 7(1), 74-82.

which means that it was significantly effective to teach reading comprehension by using the FIVES Strategy at the eleventh-grade of SMA Negeri 2 Lubuklinggau.

\section{DISCUSSION}

The research focused on improving students' reading comprehension by using FIVES Strategy. Reading comprehension is important for the students in understanding the information and message of the text when they read. In reality, the students are not able to comprehend well. It can be caused by some factor, and they are: 1) The first factor was lack of vocabulary. So, in some cases, students faced difficulty in guessing the meaning of some unknown words. Understanding the vocabulary is key to comprehend their reading text. Good reading comprehension depends on understanding the words read (Mikulecky \& Jeffries, 2007:26). But in reality, the students had difficulty in understanding the words they faced in reading text, so it gave a bad effect on their reading comprehension. By using the FIVES strategy, the students were trained to guess the meaning of the unknown words that they face in the text because in FIVES strategy, they are asked to recognize the meaning of the text context when they read. V in FIVES supports the students to notice the interesting, important, unfamiliar word in the text to know the message that the writer conveys of the text. 2) The second factor was their interest in learning English. English as a foreign language is not easy to be learned by the students, and it is also caused some students are not interested to learn. So, students are bored in the classroom, and it caused the students' comprehension to be low.

It means that the students still have difficulties in their reading comprehension, and they need certain strategies to develop their reading ability in comprehending the texts. Because of the reasons above, the researcher applied the FIVES strategy to help the students difficulties. Based on the researcher when conducting the research, the FIVES strategy was effective to be problem-solving for the students. Each component of FIVES supports the students in improving their reading comprehension, especially in the report text. Mary \& Shea (2016:99) stated that components in FIVES present capability in understanding the text content and vocabulary used in the text. The students are given an opportunity to share their ideas, their knowledge, their experience in front of their friends relate to the topic of the text, which they discussed. FIVES provides how the students achieve the outcome of reading comprehension through teaching them about useful of reading skills, allowing enough time to supported practice with each, and providing with models of strategies across genres of texts for authentic purposes (Mary \& Shea, 2016:15). Based on the researcher experience when conducting this research, the researcher accommodated $2 \times 40$ minutes for each meeting and a report text, which, in each session, the students were given different types of report text. So, the class ran effectively while conducting the research, and it affected the improvement of students' scores.

According to Minimum Mastery Criteria (MMC) in SMA Negeri 2 Lubuklinggau, the students categorized success if the students score 71 and above. If the students obtained lower than 71, it means that the students failed. Because of some factors above, the researcher decided to teach reading comprehension using the FIVES strategy. After the treatment, the researcher gave the students pre-test in order to observe their score after the treatment by the researcher. There was a significant 
Celtic: A Journal of Culture, English Language Teaching, Literature and Linguistics

Vol. 7, No. 1, June 2020.

E-ISSN: 2621-9158 P-ISSN:2356-0401

http://ejournal.umm.ac.id/index.php/celtic/index

difference between students' scores in the pre and post-tests. The average score in the pre-test was 61.81, while the average in the post-test was 78.06. It meant that the use of the FIVES strategy was significantly effective in improving students' reading comprehension. Furthermore, the researcher found the result paired sample t-test was 10.167. It was higher than the t-table was 1.689 . So, It means the alternative hypothesis was accepted, which means that it was significantly effective to teach reading comprehension by using the FIVES strategy for the eleventh-grade students of SMA Negeri 2 Lubuklinggau.

\section{CONCLUSION}

The FIVES strategy is a strategy that is used in this research. After the researcher collected and analyzed the data, the result of students' scores showed a significant difference between the students' scores before and after the students were given the treatment. The result of students' scores after the students gave the treat was in a good category. It can be compared with students' scores without taught by FIVES strategy. Based on the findings of the research, using the FIVES strategy in teaching reading at the eleventh-grade students of SMA Negeri 2 Lubuklinggau was significantly effective. The average score in the pre-test was 61.81 , and the average score in the posttest was 78.06. It can be seen the progress of students' scores; it was from the failed category to the passed category. In can be concluded that this research was a success, because there was significant progress on the result of students' scores in pre-test and post-test. There are some benefits of using the FIVES strategy to the students. First, students are more active in learning reading. Second, it trains students on how to work in a group effectively, they can work together and communicate with each other. Third, students can increase their vocabulary because in every text they will find new vocabulary. Five, it improves their critical thinking.

After the researcher conducted this research, the researcher proposed some suggestions for the next researcher to get better in the teaching and learning process than the previous research. For future researchers, the result of this research is expected to know more about the students' ability and the researcher that the next researcher used FIVES strategy to teach different English skills.

\section{REFERENCES}

Antoni, D. (2017). The Effect of Anticipation Guide Strategy and Students' Reading Interest on Students' Reading Comprehension at Grade XII of SMKN 1 Pariaman. English Language Teaching and Research. 1(1). 65-76

Brown, H. D. (2004). Language assessment: principles and classroom practices. New York: Pearson Education.

Caldwell, J. S. (2008). Reading assessment: a primer for teachers and coaches (2 $\left.{ }^{\text {nd }} \mathrm{ed}.\right)$. New York: The Guilford Press.

Fraenkel, J. R., \& Wallen, N. E. (2009). How to design and evaluate research in education (7th ed.). New York: McGraw Hill Education.

Gay, L. R., Mills, G. E., \& Airasian, P. (2012). Educational research: Competencies for analysis and applications (10th ed.). United States of America: Pearson Education.

Hadyan, R. (2013). Implementation of the cooperative learning method in teaching reading comprehension. Journal of English and Education, 1(2), 57-64. 
Sari, S., Oktaviani, A. \& Yulfi. (2020). The use of fives strategy to teach reading comprehension for eleventh graders. Celtic: A Journal of Culture, English Language Teaching, Literature, \& Linguistics, 7(1), 74-82.

Mikulecky, B. S., \& Jeffries, L. (2007). Advanced reading power: : extensive reading, vocabulary building, comprehension skills, reading faster. New York: Pearson Education.

Nuriati., Ohoiwutun, J. E., \& Mashuri. (2015). Improving students' reading comprehension by using buzz group technique. E-Journal of English Language Teaching Society, 3(2), 1-10.

Rustam, A. (2016). Dasar-dasar Statistik. Kolaka: Putri Yolanda.

Shea, M., \& Roberts, N. (2016). Fives: an integrated strategy for comprehension and vocabulary learning. Journal of Inquiry \& Action in Education, 8(1), 95-97.

Syaprizal. (2016). Using pictorial context in pre reading in reading activity to the eighth grade students of smp negeri air satan. Jurnal Perspektif Pendidikan, 10(1), 23-31.

Tankersley, K. (2003). The threads of reading: Strategies for literacy development. Virginia: Association for Supervision and Curriculum Development.

Walliman, N. (2011). Research methods: The basics. New York: Routledge.

Westwood, P. (2001). Reading and learning difficulties: Approaches to teaching and assessment. Victoria: Acer Press. 